\title{
ЦЕННОСТНЫЕ ОСНОВЫ КАЗАХСТАНСКОЙ МОДЕЛИ ОБЩЕСТВЕННОГО СОГЛАСИЯ И НАЦИОНАЛЬНОГО ЕДИНСТВА
}

\author{
${ }^{1}$ Наталья Калашникова, ${ }^{2}$ Жулдызай Искакова, ${ }^{3}$ Айсана Кахарман, ${ }^{4}$ Ван Лулу \\ Казахстан, Нур-Султан, ЕНУ им. Л.Н. Гумилева \\ ${ }^{1}$ доктор политических наук, профессор кафедры политологии \\ 2 докторант кафедры политологии, \\ ${ }^{3}$ магистрант кафедры политологии \\ ${ }_{4}$ магистрант кафедры политологии (Китайская народная республика)
}

\section{DOI: https://doi.org/10.31435/rsglobal_ws/30112019/6784}

\section{ARTICLE INFO}

Received: 29 September 2019

Accepted: 18 November 2019

Published: 30 November 2019

\section{KEYWORDS}

ethnic policy,

Kazakhstan model,

values,

Assembly of people of Kazakhstan,

social policy,

multi-ethnic state.

\begin{abstract}
The Republic of Kazakhstan is a multi-ethnic state, which is home to more than 100 ethnic groups and more than 20 confessions. The study of the main directions of the state ethnic policy of Kazakhstan, the formation of a model of social development, the study of value potential, as well as the identification of new trends consolidating society, is an urgent task for scientists and researchers not only from Kazakhstan, but also from other countries. The article focuses on the modern agenda, the study and development of eth-no-political processes in the country and the world, models of national policy of different countries, its fun-damental and value bases. For Kazakhstan's society, the key role in maintaining stability, strengthening na-tional unity and public agreement is played by the Assembly of people of Kazakhstan, which is a unique socio-political institution with a constitutional status clearly defined by legislative regulation.
\end{abstract}

Citation: Наталья Калашникова, Жулдызай Искакова, Айсана Кахарман, Ван Лулу. (2019) Cennostnye Osnovy Kazahstanskoj Modeli Obshchestvennogo Soglasiya i Nacional'nogo Edinstva. World Science. 11(51), Vol.3. doi: 10.31435/rsglobal_ws/30112019/6784

Copyright: (C) 2019 Наталья Калашникова, Жулдызай Искакова, Айсана Кахарман, Ван Лулу. This is an open-access article distributed under the terms of the Creative Commons Attribution License (CC BY). The use, distribution or reproduction in other forums is permitted, provided the original author(s) or licensor are credited and that the original publication in this journal is cited, in accordance with accepted academic practice. No use, distribution or reproduction is permitted which does not comply with these terms.

Введение. Мир XXI века представляет собой достаточно неоднородную этноконфессиональную структуру, сочетающую в себе несколько тысяч этнических общностей (нации, народности, этнические группы, племена и др.), отличающихся как численностью, так и уровнем социально-экономического развития (226 государств, 3-5 тысяч этносов).

Вопросы взаимодействия народов и культур остаются одними из главных составляющих общественного развития как на уровне государства, так и на уровне межгосударственного взаимодействия. Данным вопросам посвящено множество научных трудов, однако в современном, интенсивно меняющемся мире, вопросов становится больше, чем ответов.

Важно отметить, что в задачи ученых входит не только попытка определить основные понятия, выявить закономерности, но и выработать своего рода модель как структурной и функционирующей системы, выделить признаки, зависящие от стремительно изменяющихся условий общественного развития, ее специфику.

Очевидно, что недооценка важности проблемы мирного и толерантного проживания различных этнокультурных групп могут, в конечном итоге, перерасти в сложные общественные взаимоотношения в рамках не только одного государства. Это означает, что вопросы этнокультурных взаимодействий чрезвычайно важны как для Казахстана, страны, где проживают свыше 100 этносов, так и для мира в целом. Уникальный опыт, основанный на изучении ценностей миропорядка, 
национального единства, культурной, семейной и молодежной политики, несет в себе глубинные корни поликультурной цивилизации, служит основой для разработки основных концептов государственной политики, направленных на консолидацию общества и миропорядок.

Это является определенным ценностным вкладом в историю и развитие мировой цивилизации, а также в систему межэтнических и межгосударственных связей. Ведь почти все страны не однородны по своему этническому составу. В мире по данным ООН насчитывается немного моноэтничных государств, и полиэтничность в странах в связи с развитием геополитического ландшафта и активными иммиграционными процессами будет расширяться и укрепляться.

Для многих полиэтнических государств главная задача заключается в создании демократических институтов, в которых были бы представлены интересы всех этнических групп. Решение этой задачи лежит в плоскости создания комплекса условий формирования и реализации политики межкультурного диалога, общественного согласия и общенационального единства. Особенно актуальной такая политика является при наличии зримых этнических, религиозных и культурных различий внутри негомогенных сообществ.

Целью данной работы является выявление основных особенностей, типологий национальных моделей разных государств, а так же казахстанской модели общественного согласия и общенационального единства, базовых ценностных ее основ и основополагающих принципов казахстанской национальной политики.

Результаты исследования. Проведенный анализ показывает, что при формировании казахстанской модели этнополитики был изучен широкий опыт полиэтничных и поликонфессиональных стран мира. Сегодня в мире достаточно большое количество моделей межэтнических отношений и управления ими. К примеру, в связи с глобализацией и высокой динамикой мировых миграций особое значение приобрёл вопрос о мультикультурализме [1]. Особенно он актуален для стран Западной Европы, где все четче прослеживается состояние демографического давления и потеря способности к быстрой социокультурной «переработке» прибывающих иммигрантов. Как следствие, ряд стран данного континента теряют свою национальную идентичность.

В целом же, одной из первых стран, которая официально провозгласила мультикультурализм государственной политикой, стала Канада. Суть канадской модели мультикультурализма состояла в том, чтобы через специальные программы и службы оказывать поддержку этнокультурным ассоциациям и помогать меньшинствам в преодолении препятствий, которые мешают их полноправному участию в жизни канадского общества. К концу 80-х годов прошлого века мультикультурализм стал конституционной нормой благодаря принятию «Канадской хартии прав и свобод» и затем целого пакета специальных законов, направленных на поддержание уважения к различным культурам и их полноценное функционирование [2].

В мировой практике понятие мультикультурализм не однородно. С одной стороны, это простое наличие в рамках определённого географического и социально-политического пространства групп людей, имеющих разные культуры (языки, религии и т.д.). С другой - это политическая идеология, основанная на признании этнокультурного многообразия и идентичности в качестве источников политических прав и обязанностей в рамках единого государства. Процессы, происходящие сегодня в Европе, наглядно показали, что мультикультуральная политика существенно изменилась под влиянием быстро меняющейся современной повестки дня. Политики мультикультурализма, несущая в себе в какой-то степени и положительные тенденции, в силу своей ассимилиативности, по мнению ряда исследователей, не могла быть применена в государственной этнополитике Казахстана [3].

Другой популярной концепцией для изучения была концепция «обратной волны». В 1990-е гг. С. Хантингтон предложил модель глобального распространения демократизации, в которой использовал образ морских приливов и отливов. Он ввел в научный оборот понятие «обратной волны» (reverse wave) демократизации, обосновав почти неизбежные, но временные отступления ранней демократии под напором традиционных и более укорененных в жизни народов недемократических режимов. Эта концепция позволяет лучше понять и природу одного из парадоксов глобализации. Таким образом, в 1960-1970-е гг. западные интеллектуалы оказали существенное влияние на изменение глобальных политических стратегий, подстегнув волну традиционализации. По отношению к модернизации это была «обратная волна», отступление от идеи органического и целенаправленного обновления общества.

Плавильный котел или плавильный тигель (анг. melting pot) - это модель этнического развития, пропагандируемая в американской культуре XX века. В соответствии с данной 
парадигмой, формирование американской национальной идентичности должно было идти по формуле: «сплавления», «смешивания» всех народов. Культурная ассимиляция в XVIII-XIX веках постепенно достигалась преимущественно за счет навязывания населению страны единого языка, насильственного подавления местных или привнесенных языков, жестких запретов на функционирование локальных культур. На совершенно иных основах утверждалась гражданская интеграция. Она базировалась на идее дополнения множества культур единой гражданской и поощрения такой дополнительной культурной однородности косвенными методами.

В Казахстане были отдельные попытки формирования своей модели по принципу американской нации (в период обсуждения проекта Доктрины национального единства Казахстана), однако ни на экспертном, ни в общественном восприятии эта идея не была поддержана в обществе.

Другая концепция, основывающаяся на модели «лоскутного одеяла» принципиально не встраивается в казахстанскую этнополитику, в силу тех исторических, социально-экономических и др. условий, которые отличают Казахстана от данных государств. Вместе с тем, представляет интерес опыт полиэтничного многообразия Китая, где национальная политика выстраивалась по модели «лоскутного одеяла», ядром которой является основной «лоскут» - ханьцы $(91,96 \%)$, остальное население Китая - представители 56 этносов. Одной из особенностей национальной политики Китая поддержка этнического разнообразия посредством принятия стратегических документов, в которых акцент сделан на содействие общему развитию всех этнических групп, защита и развитие культуры меньшинств. Примечательным является не акцент на ассимиляцию как основной составляющей мультикультурализма, а на развитие языкового многообразия (в Китае 21 этническая группа, в общей сложности используется 27 языков) и особенности семейной политики этнических меньшинств. Здесь разработана политика планирования семьи для соответствующих этнических меньшинств (политика рождаемости этнических меньшинствах шире: как правило, семьи этнических меньшинств могут иметь двух или трех детей, этнические меньшинства приграничных районов могут иметь более трех детей, в Тибетском автономном районе семьи тибетских фермеров и скотоводов могут иметь детей без ограничений) [4].

Вместе с тем, шесть основополагающих принципов этнополитики, которых придерживается Казахстан, конституционные и другие законодательные основы сформировали свой собственный путь ее развития. Однако опыт западных государств служит в определенной степени ориентиром в сфере современного политического управления, в том числе и этнополитическими процессами [5]. Остаются проблемными зонами не только для Казахстана, но и Центрально-Азиатского региона - это раздробленность политического менеджмента этнополитики и иммиграция, которая так же интенсивно развивается в мире.

К истории вопроса о Казахстанской модели. Изучение опыта политики крупных полиэтничных и поликонфессиональных стран, с учетом этнического многообразия, с первых дней независимого развития запустил процесс формирования и развития этногосударственной политики и выработки собственной модели развития казахстанского общества, в том числе и в межэтнической и конфессиональной сферах. Анализ научных работ отечественных и зарубежных исследователей показывает, что большинство ученых сходятся во мнении, что за годы независимости в Казахстане была создана собственная национальная модель межэтнических отношений, при этом в процесс были вовлечены как государство, так и общественные институты.

Как отмечается отечественными и зарубежными учеными Модель прошла ряд этапов эволюции. Так, к концу 2000-х текущего столетия в Казахстане были окончательно сформированы базовые принципы и ценностные основы уникальной модели межэтнического взаимодействия. Во первых - это деполитизация межэтнических отношений, которая выражалась в недопущении формирования политических сил и движений по национальному или религиозному признаку; вовторых, образование и развитие такого института как Ассамблея народа Казахстана (АНК); и втретьих, представленность интересов разных этнических групп в высшем законодательном органе Парламенте РК. Это доказывает, что в Казахстане меры по поддержанию межэтнического и межконфессионального равновесия носят комплексный характер. Базовые казахстанские ценности, идущие из глубин вековой степной цивилизации: солидарность, миропорядок, благотворительность, этноволонтерство, семейные традиции уважительного отношения к старшим и др., положены в основу казахстанской модели общественного согласия и общенационального единства. С учетом этих особенностей Модель развивается, корректируется и совершенствуется, и является чувствительным барометром изменений в обществе и государственной национальной политике. 
Таким образом, Казахстан за годы независимости определил свой подход, продемонстрировал миру свою стратегию, выработал собственную действенную модель, которая работает и развивается. Модель межэтнического ноу-хау на многих международных площадках, переведенная на языки ОБСЕ, признана эффективной. Сегодня «брендовые» проекты АНК, способствующие обновлению Казахстанской модели, и «работающие» на сплочение нации, привлекают не только казахстанское научно-экспертное сообщество, но и зарубежных исследователей в сфере межэтнических отношений, тем самым открываются новые просветительские возможности для ее модернизации. Таким образом, в Казахстане сложился особый тип межэтнического взаимодействия, в том числе благодаря новейшим коммуникативным технологиям. В этом смысле АНК становится ключевым механизмом «мягкой силы», а ее традиционные общенациональные проекты: «Память во имя будущего»; форум СВМДА; «Беседы на Шелковом пути»; «День Благодарности»; исследования по «Алаш» и др. наполняются новыми интеграционными и консолидирующими смыслами, где ядром выступает многогранная история кочевых народов, гуманистические традиции этноволонтерства и благотворительности казахов и казахстанских этносов.

Выводы и предложения по модернизации Казахстанской модели. По мнению зарубежных исследователей [6], Казахстан в целом достиг своей цели по построению и поддержанию межэтнического мира внутри страны. Такие факторы начала 90-х годов как полиэтнический состав населения, наличие конфликтного потенциала, спровоцированного целым комплексом проблем социально-экономического характера, не стали причиной конфликтов на межэтнической почве. В Республике были максимально задействованы механизмы конструктивного взаимодействия между этносами и созданы механизмы предупреждения и разрешения конфликтов при активном вовлечении общественных институтов. При этом в Казахстане на сегодняшний день экспертами выдвигаются предложения по дальнейшему укреплению исследуемого направления. В частности, проведенный анализ позволил выделить следующие вызовы и предложения:

1. Необходимо повышать уровень информированности граждан о деятельности АНК и ее структур, способствующих консолидации общества.

2. Необходимость модернизации традиционных проектов АНК и разработка новых, особенно в социальной сфере, являющиеся в определенной степени барометром настроения общества;

3. Необходимость формирования кадрового потенциала лидеров этнокультурных объединений нового поколения, основанного на талант - менеджменте и формуле личного успеха;

4. Расширение нормативного правового регулирования сферы межэтнических отношений, совершенствование базовых документов: ЗРК «Об Ассамблее народа Казахстана», «О государственном социальном заказе, грантах и премиях для неправительственных организаций в Республике Казахстан», «Об общественных объединениях», Концепции развития АНК до 2025 года, Доктрины национального единства Казахстана;

5. Активное включение в деятельность АНК и ее Научно-экспертного совета представителей науки этносов, широко используя возможности этнокультурных объединений для расширение научно-образовательных связей;

6. Казахстанская модель этнополитики отличается неразрывной связью с государственной политикой в целом. Специфика ее состоит в комплексном характере, когда деятельность каждого государственного органа и общественного объединения неразрывно связана с продвижением принципов общественного согласия и консолидации общества. Представляется целесообразным выработать государственную стратегию управления рисками в сфере этнополитики, адекватную современным процессам.

Изложенные выводы и наблюдения авторов, позволяют утверждать, что казахстанский опыт межэтнического и межконфессионального согласия является уникальной консолидирующей общество Моделью развития данного направления государственной политики. Однако, с учетом имеющейся специфики казахстанского общества, традиций и истории, современных вызовов и угроз, в полной мере нельзя утверждать об ее универсальности, она постоянно требует совершенствования, более широкого вовлечения этносов к участию в общегосударственных делах. В то же время, основные принципы и выработанные инструменты, эффективно применяемые в Казахстане в сфере национальной политики, могут учитываться другими государствами. 


\section{ЛИТЕРАТУРА}

1. Сахарова В.В. Мультикультурализм и политика интеграции иммигрантов: сравнительный анализ опыта ведущих стран Запада. - СПб.: Златоуст, 2011 - 176 с.

2. Кошелев Л.В., Тишков В.А. История Канады. - М., 1982.

3. Калашникова Н.П. Казахстанская модель общественного согласия и общенационального единства: история формирования и новые тренды ее модернизации (основные пролегомены исследования). - НурСултан, 2019. - 28 с.

4. Политика и практика меньшинств Китая. - URL: https://www.fmprc.gov.cn/ce/cohk/chn/xwfb/zfbps/t55528.htm [дата обращения: 06.12.2019]

5. Искакова Ж.А. Государственная семейная политика Казахстана: анализ текущего состояния и тенденции развития [Текст] / Ж.А. Искакова // Казахстан-Спектр. - 2019. - №4. - С. 2007. - № 4. - С. $76-84$.

6. Якушева Ю.В. Динамика межэтнических отношений в Республике Казахстан (1991-2010 гг.). дисс. к.и.н. Москва, 2015. 